\title{
Kinerja Usahatani dan Motivasi Petani dalam Penerapan Inovasi Varietas Jagung Hibrida pada Lahan Kering di Kabupaten Lombok Timur
}

\section{Farming Performance and Motivation of Farmers in The Application of Innovation Hybrid Corn Varietiess on Dryland in Eastern Lombok District}

\author{
Ni Made Nike Zeamita Widiyanti ${ }^{1}$, Lukman M. Baga ${ }^{2}$, dan Heny K. Suwarsinah ${ }^{2}$ \\ ${ }^{1)}$ Program Studi Pascasarjana Agribisnis, Fakultas Ekonomi Manajemen IPB, Bogor \\ ${ }^{2)}$ Departemen Agribisnis, Fakultas Ekonomi Manajemen IPB, Bogor
}

\begin{abstract}
Some of the constraints for farmers in dry land are limitation of water supply, low education and low income. However, these constraints do not eliminate the desire of farmers to adopt hybrid corn varieties innovation. That condition presumabily caused by the high motivation of the farmers. Motivation is one of the important aspects that may influence the decision of farmers to adopt innovatios. This research attempt to analyze the differences between the performance of hybrid and non-hybrid farmers, to analyze the level of motivation and the factors that influence the motivation of farmers in the application of innovative hybrid corn varieties. Analysis methods which used were independent sample t-test, mann-whitney test and rank spearman correlation test. The results reveal there is a significant difference between the performance of hybrid and non-hybrid farmers. In normal condition, the hybrid farmers can produce an average of 11,45 tons per hectare, while the non-hybrid farmers can produce an average of 7,43 tons per hectare. There are differences in the level of motivation between the early majority farmers and the late majority farmers. The motivation of the early majority hibrid farmers is lower than the late majority hybrid farmers. Further, determinats that influence the motivation of farmers' application of innovative hybrid corn varieties are experiences on farming, number of dependents, size of farmland, cosmopolitan nature and availability of capital.
\end{abstract}

Keywords: farming performance, hybrid corn, innovation, motivation

\begin{abstract}
Abstrak
Beberapa kendala petani pada lahan kering yaitu keterbatasan air, pendidikan rendah, dan pendapatan yang rendah. Kendala tersebut tidak menghilangkan keinginan petani untuk mengadopsi inovasi varietas jagung hibrida. Kondisi ini diduga karena motivasi petani yang tinggi. Motivasi merupakan salah satu aspek penting yang mempengaruhi keputusan petani untuk mengadopsi inovasi. Tujuan penelitian ini yaitu untuk menganalisis perbedaan kinerja usahatani antara petani hibrida dan non hibrida, untuk menganalisis tingkat motivasi dan faktor-faktor yang mempengaruhi motivasi petani dalam penerapan inovasi varietas jagung hibrida. Metode analisis data yang digunakan adalah analisis uji beda (uji-t), uji mann-whitney dan uji korelasi rank spearman. Hasil menunjukkan bahwa terdapat perbedaan kinerja usahatani antara petani hibrida dan non hibrida. Pada kondisi normal, petani hibrida dapat memproduksi rata-rata 11,45 ton per hektar, sedangkan petani non hibrida dapat memproduksi rata-rata 7,43 ton per hektar. Terdapat perbedaan tingkat motivasi antara petani hibrida mayoritas awal dan mayoritas akhir. Motivasi petani hibrida mayoritas akhir lebih tinggi dibandingkan mayoritas awal. Faktor-faktor yang mempengaruhi motivasi petani dalam penerapan inovasi varietas jagung hibrida yaitu, pengalaman berusahatani, jumlah tanggungan keluarga, luas lahan garapan, sifat kosmopolit dan ketersediaan modal.
\end{abstract}

Kata kunci : jagung hibrida, kinerja usahatani, inovasi, motivasi

\section{Pendahuluan}

Jagung merupakan salah satu tanaman pangan yang sangat penting dan strategis dalam upaya pembangunan pertanian di Indonesia karena menjadi salah satu tanaman pokok bagi kebutuhan

Korespondensi Penulis

E-mail:zeamita91@gmail.com manusia. Jagung di Indonesia digunakan sebagai bahan pangan dan bahan pakan ternak. Hampir 50 persen kebutuhan jagung nasional digunakan untuk industri ternak. Peningkatan jumlah impor jagung menunjukkan bahwa daerah-daerah sentra tanaman jagung di Indonesia masih belum dapat memenuhi 
permintaan jagung nasional. Berdasarkan data BPS pada tahun 2015 Indonesia memproduksi jagung pada tahun 2014 sebanyak 19,03 juta ton dalam bentuk pipilan kering. Berdasarkan data tersebut dapat dilihat bahwa terjadi peningkatan jumlah permintaan jagung nasional yang diikuti dengan peningkatan produksi, namun jumlah impor tetap tinggi. Pada tahun 2013 Indonesia mengimpor jagung sebanyak 3,255 juta ton dan diperkirakan akan meningkat pada tahun 2014 hingga 4 juta ton.

Upaya meningkatkan produksi untuk menekan impor jagung pemerintah perlu memanfaatkan lahanlahan pertanian yang berpotensi di Indonesia. Salah satu lahan pertanian yang berpotensi dan masih belum banyak dimanfaatkan adalah lahan kering. Lahan kering merupakan lahan sumber airnya bergantung pada curah hujan. Lahan kering pertanian di Indonesia mencapai $86,24 \%$ dari total luas lahan pertanian di Indonesia (Setyobudi, 2013). Salah satu daerah yang berpotensi dalam mengembangkan komoditas jagung pada lahan kering adalah Provinsi Nusa Tenggara Barat. Daerah NTB merupakan daerah yang sangat berpotensi bagi pengembangan jagung pada lahan kering karena sebesar 1,8 juta ha lahannya merupakan lahan kering (Vizi, 2010). Kabupaten Lombok Timur merupakan salah satu daerah lahan kering di NTB, dengan luas lahan kering sebesar $71,73 \%$ dari luas lahan Kabupaten Lombok Timur.

Petani di Kabupaten Lombok Timur menanam jagung dengan menggunakan inovasi varietas Hibrida. Jagung Hibrida merupakan salah satu inovasi varietas unggul yang diciptakan untuk meningkatkan produktivitas jagung. Jagung Hibrida yang telah dilepas, baik oleh Badan Litbang Pertanian maupun swasta memiliki potensi hasil 9,0-14,0 ton/ha (Exsact, 2013). Tujuan penerapan inovasi varietas hibrida khususnya pada lahan kering tercapai apabila memperhatikan faktor sosial budaya masyarakat setempat. Salah satu faktor tersebut adalah motivasi petani. Motivasi merupakan salah satu aspek penting yang mempengaruhi tindakan petani dalam sebuah penerapan inovasi pada usahataninya. Oleh sebab itu, penerapan inovasi varietas hibrida pada lahan kering diduga tidak terlepas dari adanya faktor motivasi petani. Motivasi diduga muncul karena adanya dorongan dari dalam diri petani dan lingkungan sekitar petani (Wahjo, 1984; Handoko, 1992; Winardi, 2002).

Pada kondisi lahan kering tentu saja mengalami keterbatasan dalam penyediaan air sebagai salah satu faktor penting dalam kegiatan pertanian. Kondisi tanah pada lahan kering sangat peka terhadap erosi pada musim hujan, meskipun intensitas hujannya tidak berlangsung lama (Suriadi, 2012). Pada umunya petani pada lahan kering di Kabupaten Lombok Timur tergolong miskin dan memiliki pendidikan yang rendah karena pendapatan petani yang dimiliki masih rendah sehingga akses untuk mendapatkan pendidikan masih sulit didapatkan. Menurut data BPS 2013, jumlah persentase penduduk miskin di Kabupaten Lombok timur sebersar 26,35\% dari total penduduk miskin di NTB. Jumlah penduduk yang berjenis kelamin laki-laki sebanyak 61,97 $\%$ memiliki status tidak sekolah, tidak tamat SD, dan Tamat SD sedangkan untuk penduduk berjenis kelamin perempuan sebanyak 66,64\%.

Salah satu kendala dalam upaya untuk meningkatkan kinerja jagung adalah rendahya tingkat adopsi petani dalam penggunaan varietas unggul. Hal serupa juga dikatakan oleh Suriadi (2012), bahwa kendala dalam peningkatan produktivitas salah satunya rendahnya adopsi petani terhadap inovasi. Namun, hal ini tidak berlaku pada petani lahan kering di Lombok Timur. Terdapat banyak petani di Kabupaten Lombok Timur yang telah menerapkan inovasi tersebut. Kegiatan usahatani dengan inovasi varietas hibrida masih banyak digunakan oleh petani hingga saat ini, walaupun kendala masih banyak ditemui, terutama pada penyediaan pupuk organik yang membantu pada pengikatan air di dalam tanah. Selain itu, harga varietas hibrida juga cukup mahal bagi petani miskin. Harga varietas hibrida di tingkat petani berkisar antara Rp50.000-Rp70.000 per kilogram (Suriadi, 2012).

Salah satu aspek yang ikut menentukan keberhasilan dalam menerapkan sebuah inovasi, yang dalam hal ini inovasi varietas hibrida adalah melalui penggerakan motivasi. Motivasi petani merupakan salah satu aspek yang penting untuk dikaji, mengingat hal tersebut terkait pada tindakan yang dapat menentukan prestasi kerja petani 
dalam berusahatani. Kondisi ini sangat menarik untuk dikaji, melihat keterbatasan petani pada lahan kering baik dari petaninya sendiri maupun kondisi alamnya, namun tidak sedikit petani yang mau menerapkan inovasi varietas hibrida. Melalui penerapan inovasi varietas hibrida petani dapat memanfaatkan lahan keringnya baik untuk meningkatkan kinerja usahataninya. Berdasarkan kondisi tersebut akan diadakan pengkajian motivasi yang mendorong petani melaksanakan inovasi varietas hibrida pada lahan kering. Penting untuk diidentifikasi mengenai motivasi petani, sehingga akan diketahui faktor yang menyebabkan kegiatan tersebut dilakukan. Berdasarkan uraian di atas, maka tujuan dari penelitian ini adalah: (1) mengganalisis kinerja usahatani jagung pada penerapan inovasi varietas hibrida pada lahan kering di Kabupaten Lombok Timur; (2) menganalisis tingkat motivasi petani jagung dalam penerapan inovasi varietas hibrida pada lahan kering di Kabupaten Lombok Timur; dan (3) menganalisis faktor-faktor yang mempengaruhi motivasi petani dalam menerapkan inovasi varietas hibrida pada lahankeringdiKabupaten LombokTimur.

\section{Metode Penelitian}

\section{Lokasi dan Waktu Penelitian}

Penelitian ini akan dilakukan di Kecamatan Pringgabaya, Kabupaten Lombok Timur. Pemilihan tempat ini dilakukan secara purposive, berdasarkan pertimbangan bahwa Kabupaten Lombok Timur merupakan salah satu sentra produksi jagung di Nusa Tenggara Barat dan jagung merupakan salah satu komoditas unggulan Kabupaten Lombok Timur, hal ini dapat terlihat pada sebagian besar petani mengusahakan jagung. Pemilihan Kecamatan Pringgabaya didasarkan bahwa terdapat responden sesuai dengan kroteria penelitian, yakni terdapat petani hibrida (early majority dan late majority) dan non-hibrida, selai itu Kecamatan Pringgabaya merupakan sentra tanaman jagung, serta memiliki luas panen dan produksi tertinggi di Kabupaten Lombok Timur. Waktu penelitian akan dilakukan pada bulan Mei-Juni 2015.

\section{Jenis dan Sumber Data}

Data yang digunakan dalam penelitian ini terdiri dari data primer dan data sekunder. Data primer diperoleh dari hasil pengisisan kuisioner dengan melakukan wawancara langsung dengan responden yaitu petani jagung hibrida dan non hibrida. Data sekunder diperoleh dari Unit Penyuluhan Pertanian, serta dari pengumpulan informasi kepustakaan, internet dan literatur lainnya.

\section{Metode Penentuan Sampel}

Populasi pada penelitian ini adalah petani jagung yang menerapkan inovasi varietas jagung hibrida dan yang tidak menggunakan di Kabupaten Lombok Timur. Unit analisis dalam penelitian ini adalah petani jagung yang menjadi pengambil keputusan utama dalam usahtaninya. Metode penentuan sampel dilakukan secara purposive sampling, karena data mengenai jumlah populasi petani yang menggunakan dan yang tidak menggunakan varietas jagung hibrida tidak tersedia. Jumlah sampel yang digunakan sebanyak 100 responden.

Pada tujuan pertama untuk menganalisis kinerja usahatani, sampel dibagi menjadi dua sub populasi, yakni petani yang tidak menerapkan inovasi (20 responden) dan petani yang menerapkan inovasi (80 responden). Menjawab tujuan kedua mengenai tingkat motivasi hanya digunakan sub populasi petani yang menerapkan inovasi sebanyak 80 responden. Kemudian dari sub populasi ini dibagi lagi menjadi dua kategori sub populasi, yakni early majority dan late majority masingmasing sebanyak 40 respoonden. Pemilihan kedua kategori adopter ini atas pertimbangan bahwa kedua kategori ini persentase keberadaannya dalam pupolasi paling tinggi, masing-masing sebesar 34\% (Rogers, 1983). Menjawab tujuan ketiga untuk mengetahui faktor-faktor yang mempengaruhi motivasi petani digunakn sub populasi petani yang menggunakan inovasi sebanyak 80 responden.

\section{Metode Analisis Data}

Penelitian ini bersifat deskriptif dengan menggunakan pendekatan secara kualitatif 
dan kuantitatif. Analisis kuantitatif dilakukan untuk melihat kinerja usahatani yang terdiri dari produktivitas, harga, dan pendapatan. Analisis kualitatif digunakan untuk menganalisis tingkat motivasi dan faktor-faktor yang mempengaruhi motivasi. Pengolahan data dilakukan dengan menggunakan SPSS dan minitab.

\section{Analisis Usahatani}

Perhitungan produktivitas dilakukan dengan membagi total produksi per satuan lahan. Sedangkan untuk pendapatan usahatani dilakukan dengan analisis usahatani. Terdapat beberapa istilah penting yang harus diketahui pada saat melakukan analisis usahatani (Suratiyah, 2011), yaitu: Produk total (Y) adalah jumlah produksi per usahatani dengan satuan kilogram $(\mathrm{kg})$. Harga produk (P) adalah harga per unit dengan satuan $\mathrm{Rp} / \mathrm{kg}$. Penerimaan atau hasil produksi (TR) adalah jumlah produksi dikalikan harga produk (TR=Y.P) dengan satuan rupiah (Rp).

(a) Biaya variabel per unit (VC) adalah biaya yang bergantung pada besar kecilnya produksi (Prawirokusumo, 1980). Biaya ini digunakan untuk membeli atau menyediakan bahan baku yang habis dalam satu kali produksi, misalnya biaya sarana produksi dan tenaga kerja luar per usahatanni dengan satuan rupiah (Rp).

(b)Biayatetap(FC)adalahbiayayangdipengaruhioleh besarkecilnyaproduksi(Mubyarto, 1994), misalnya biaya sewa lahan, pajak lahan, dan penyusutan alat.

(c) Biaya penyusutan alat dapat dihitung dengan rumus di bawah ini:

Penyusutan per bulan=(biaya-nilai sisa $($ residu $)$ )/ (umur ekonomis)

(d) Biaya total (TC) adalah jumlah biaya variabel dan biaya tetapp dengan satuan rupiah (Rp).

(e) Pendapatanpetani(I)adalahselisihantarapenerimaan total dengan biaya total dengan satuan rupiah (Rp).

(f) Tenaga kerja yang dicurahkan adalah jumlah tenaga kerja keluarga ditambah dengan jumlah tenaga kerja luar keluarga per usahatani dengan satuan HOK.

\section{Uji Beda Dua Sampel Tidak Berhubungan (Independent Sample T Test)}

Uji dua sampel tidak berhubungan ini merupakan uji yang digunakan untuk mengetahui ada atau tidaknya perbedaan rata-rata antara dua kelompok sampel yang tidak berhubungan. Jika hasil yang didapat dimiliki perbedaan, maka uji ini akan memeperlihatkan rata-rata manakan yang lebih tinggi. Data yang biasa digunakan dalam uji ini berupa data interval atau rasio (Priyatno, 2008). Berikut merupakan rumus perhitungan pada uji $t$ ini (Sugiyono, 2007). Uji ini digunakan untuk mengetahui perbedaan kinerja usahatani antara petani hibrida dan non-hibrida.

\section{Uji Mann-Whitney}

Uji Mann-Whitney berpasangan digunakan untuk mengetahui perbedaan tingkat motivasi petani hibrida pada katagori early majority dan late majority. Uji ini berfungsi untuk mengetahui ada atau tidaknya perbedaan pada dua populasi data yang saling independen.

\section{Skala Likert}

Analisis data yang digunakan sesuai dengan tujuan penelitian. Tujuan pertama untuk mengetahui tingkat motivasi petani dalam menerapkan inovasi varietas hibrida digunakan perhitungan dengan metode skala likert. Metode dengan menggunakan skala likert digunakan untuk menganalisis tingkat motivasi petani jagung di Kabupaten Lombok Timur. Menurut Simamora (2004), skala likert adalah skala yang memberi peluang kepada responden untuk mengekspresikan perasaan mereka dalam bentuk persetujuan suatu pernyataan. Jumlah pilihan jawaban bisa tiga, lima, atau tujuh. Pilihan harus berjumlah ganjil. Data yang diperoleh dari skala likert berupa data skala ordinal, setelah itu diubah menjadi skala interval. Skor penilaian menggunakan skala likert 1-5.

\section{Uji Korelasi Rank Spearman}

Pada analisis mengenai faktor-faktor yang 
mempengaruhi motivasi petani dalam penerapan inovasi varietas jagung hibrida digunakan uji korelasi rank spearman. Uji ini digunakan untuk menguji korelasi antar dua variabel dengan pengukuran variabel minimal menggunakan skala ordinal.

\section{Hasil dan Pembahasan}

\section{Kinerja Usahatani}

Pada umumnya kinerja diukur melalui beberapa indikator, seperti produktivitas, harga, dan pendapatan. Perbedaan kinerja pada setiap petani biasanya disebabkan oleh penggunaan faktor produksi yang beragam. Berdasarkan hasil uji beda menggunakan uji $t$, terdapat perbedaan pada produktivitasdanpendapatanantarapetanihibridadan non-hibrida (Tabel 1). Namun, untuk variabel harga tidak terdapat perbedaan antara kedua petani tersebut. Produktivitas adalah rasio dari total output dengan input yang dipergunakan dalam produksi (Heady dan Dillon, 1972). Produktivitas merupakan salah satu cara untuk mengukur suatu kinerja usahatani. Produktivitas diukur dengan jumlah output per unit input (Pindyck dan Rubinfeld, 2001). Adanya penggunaan inovasi varietas hibrida dapat meningkatkan produktivitas usahatani jagung yang dilakukan petani. Ketika kondisi normal, petani mampu menghasilkan produktivitas rata-rata sebesar 11,45 ton per hektar. Berbeda halnya dengan petani non-hibrida yang memiliki produktivitas rata-rata sebesar 7,43 ton per hektar (Tabel 2).

Pada kurun waktu 2 tahun terakhir kondisi pada wilayah penelitian tidak terjadi perbedaan tingkat produktivitas, hal ini disebabkan karena petani jagung hibrida mengalami gagal panen akibat perubahan curah hujan. Petani pada umumnya menanam jagung 1 kali dalam setahun, petani memanfaatkan air hujan untuk mengairi lahannya, karenabiaya pengairan dinilaipetani sangat mahal dan dapat merugikan mereka. Kegiatan usahatani jagung Tabel 1. Hasil uji beda (Uji-T) pada variabel kinerja

\begin{tabular}{lrrr}
\hline Parameter & t hitung & Df & \multicolumn{1}{c}{ Sig. (2-tailed) } \\
\hline Produktivitas & $-6,894$ & 98 & $0,000^{*}$ \\
Pendapatan & $-12,129$ & 98 & $0,000^{*}$ \\
\hline
\end{tabular}

Keterangan : *berbeda nyata jika $\mathrm{p}<$ alpha $0,05(5 \%)$
Tabel 2 Produktivitas dan pendapatan petani responden di Kecamatan Pringgabaya

\begin{tabular}{lcc}
\hline Kategori Petani & $\begin{array}{c}\text { Produktivitas } \\
\text { (Ton/ha) }\end{array}$ & $\begin{array}{c}\text { Pendapatan } \\
\text { (Rp/ha) }\end{array}$ \\
\hline Non-hibrida & 7,43 & 3.567 .717 \\
$\begin{array}{l}\text { Early majority } \\
\text { (hibrida) }\end{array}$ & 11,90 & 8.784 .210 \\
$\begin{array}{l}\text { Late } \\
\text { (hibrida) }\end{array}$ & 11,0 & 8.098 .871 \\
\hline
\end{tabular}

yang dilakukan petani sangat bergantung padakondisi iklim dan air yang tersedia. Iklim dan air merupakan salah satu faktor internal yang mempengaruhi keberhasilan dari suatu usahatani (Hernanto, 1994). Harga merupakan salah satu faktor penting dalam perolehan pendapatan usahatani. Harga jual yang tinggi bagi petani akan meningkatkan semangat petani untuk terus berusahatani. Seluruh petani merasa harga yang diberikan oleh pedagang pengumpul masih rendah, karena biaya total yang petani keluarkan untuk kegiatan usahatani semakin hari semakin meningkat.

Harga jagung yang diperoleh petani hibrida dan non hibrida tidak memiliki perbedaan. Seluruh harga jagung baik hibrida dan non hibrida ditentukan oleh pedagang pengumpul. Penentuan harga oleh pedagang pengumpul memperlihatkan bahwa petani tidak memiliki posisi yang kuat untuk ikut menentukan harga jual jagungnya. Rata-rata petani telah memiliki pedagang pengumpul tersendiri yang biasa membeli hasil produksinya. Petani mejual jagung dalam bentuk pipilan dan tongkol. Harga yang diberikan berbeda-beda bergantung pada kondisi jagung. Jagung tongkol dibeli dengan harga berkisar Rp1.000 hingga Rp1.800 per kilogram tergantung pada jenis pemanenannya. Jika panen secara borongan, maka harga yang ditawarkan lebih murah yakni berkisar Rp1.000 hinga Rp1.300 per kilogram. Pemanenan secara borongan merupakan panen yang dilakukan oleh pedagang pengumpul yang datang sendiri ke lokasi usahatani, serta menyiapkan sendiri kendaraan untuk mengangkut hasil panen petani. Jika petani membawa hasil panennya langsung ke pedagang pengumpul maka harga yang diberikan lebih tinggi, yakni berkisar Rp1.500-Rp1.800 (Tabel 3). Menurut Soekartawi (1990) harga merupakan 
Tabel 3 Sebaran Harga Jagung Hibrida dan Non-hibrida

\begin{tabular}{lccc}
\hline Jenis jagung & \multicolumn{3}{c}{ Katagori Petani } \\
& Non-hibrida (Rp) & Early Majority (Rp) & Late Majority (Rp) \\
\hline Tongkol & $1.000-1.200$ & $1.100-1.300$ & $1.150-1.800$ \\
Pipilan & $2.300-2.600$ & 2.500 & $2.400-2.500$ \\
\hline
\end{tabular}

salah satu faktor ketidakpastian bagi petani, sehingga bila harga mengalami perubahan maka pendapatan yang diterima petani juga berubah. Kualitas jagung yang menurun dapat menyebabkan harga yang diberikan oleh para pedagang pengumpul menurun juga. Penerunan harga yang diterima petani berkisar Rp100-Rp500 per kilogram. Harga jual jagung yang berlaku dinilai tidak layak atau masih rendah bagi para petani, karena harga input produksi yang semakin hari semakin meningkat.

Salah satu faktor eksternal yang mempengaruhi keberhasilan usahatani adalah harga. Semakin baik harga yang diberikan maka petani cenderung lebih semangat untuk menjalankan usahataninya. Upaya dalam penilaian keberhasilan suatu usahatani dapat dilakukan evaluasi terutama dari sudut pandang ekonomi, salah satunya adalah pendapatan (Suratiyah, 2011). Pada penelitian ini diketahui bahwa terdapat perbedaan pendapatan antara petani non-hibrida dengan petani hibrida. Pendapatan petani hibrida lebih tinggi dibandingkan dengan petani non-hibrida. Pendapatan yang tinggi diperoleh petani hibrida didapatkan dari hasil produksi jagung yang melimpah walaupun biaya yang dikelurkan petani hibrida lebih banyak dibandingkan dengan petani non-hibrida. Pedapatan petani sangat bergantung pada tinggi rendahnya hasil produksi dan biaya yang dikeluarkan. Biaya total yang dikeluarkan petani non hibrida rata-rata sebesar Rp4.451.758 per hektar, sedangankan untuk petani hibrida sebesar Rp5.634.035 per hektar.

Hal yang berbeda terjadi ketika petani mengalami kerugian akibat perubahan cuaca. Pendapatan petani antara non hibrida dengan hibrida tidak mengalami perbedaan yang signifikan. Sama halnya dengan produktivitas usahatani, pendapatan petani hibrida menurun akibat produksi yang menurun drastis. Namun, jika dilihat dari rata-rata pendapatannya, rata-rata pendapatan petani non hibrida lebih tinggi dibandingkan degan petani hibrida. Rata-rata untuk masing-masing katagori petani yaitu petani non hibrida Rp 638.765 per hektar, early majority Rp 144.656 per hekar, dan late majority Rp 203.652 per hektar. Banyak faktor yang mempengaruhi besarnya pendapatan, salah satunya faktor internal dan eksternal dari petani, serta faktor manajemen usahatani (Suratiyah, 2011).

\section{Tingkat Motivasi Petani dalam Penerapan Inovasi Varietas Jagung Hibrida}

Motivasi merupakan dorongan yang timbul baik dari dalam diri seseorang maupun lingkungan sekitarnya yang dapat menggerakkan individu tersebut mencapai tujuannya. Motivasi petani dalam menerapkan inovasi varietas jagung hibrida merupakan dorongan yang dapat menggerakkan petani untuk mau menerapkan sebuah inovasi baru bagi masyarakat setempat, yakni inovasi varietas jagung hibrida dalam upaya peningkatan produktivitas dan pendapatan petani. Dorongan tersebut dapat dipengaruhi oleh berbagai faktor termasuk kondisi budaya tempat tinggalnya. Ratarata pada kedua katagori petani memiliki tingkat motivasi yang tinggi, masing-masing bernilai $62,25 \%$ (earlymajority) dan 65,25\% (late majority) ( Tabel 4). Sumber dorongan terbesar petani untuk menerapkan varietasjagunghibridaberasaldaridirinyasendiri,baik bagi katagori early majority dan late majority. Alasan petani menerapkan inovasi varietas jagung hibrida terbesar karena ingin meningkatkan pendapatannya. Sumber dorongan tertinggi petani ada pada dirinya sendiri. Petani cenderung ingin mencoba varietas baru yang dianggap akan memberikan hasil yang melimpah sesuai dengan keinginannya sendiri. Petani telah memahami bahwa pentingnya menerapkan inovasi varietas jagung hibrida untuk meningkatkan produksinya, serta memperbaiki usahataninya. Selain berasal dari dirinya sendiri, sumber dorongan juga berasal dari 
Tabel 4. Distribusi petani responden berdasarkan tingkat motivasi dalam menerapkan inovasi varietas hibrida

\begin{tabular}{lrr}
\hline \multicolumn{1}{c}{ Motivasi } & \multicolumn{2}{c}{$(\%)$ Rata-rata } \\
& Early majority & Late majority \\
\hline Tingkat motivasi petani & 62,25 & 65,25 \\
Sumber motivasi & & \\
Keinginan sendiri & 100,00 & 100,00 \\
Teman/tetangga/keluarga & 35,00 & 52,50 \\
Penyuluh/pemerintah & 2,50 & 12,50 \\
Alasan menerapkan inovasi varietas hibrida & & \\
Motif ekonomi & 100,00 & 100,00 \\
Motif aktualisasi diri & 77,50 & 82,50 \\
Mengisi waktu luang & 2,50 & 0,00 \\
Kuantitas dan kualitas bagus & 37,50 & 47,50 \\
\hline
\end{tabular}

tetangga, teman, keluarga, dan pihak penyuluh walaupun persentasenya masih sangat rendah. Kekuatan motivasi dapat digambarkan dari fungsi motif, harapan, dan insentif (Atkinson, 1964). Kekuatan yang menjadi alasan petani untuk bertindak adalah memperoleh hasil yang baik dalam kualitas dan kuantitas pada usahataninya, sehingga petani mau menerapkan inovasi varietas jagung hibrida. Harapan akan hasil yang baik merupakan keyakinan petani dengan apa yang mereka lakukan akan mencapai tujuannya. Nilai imbalan yang merupakan hasil yang ingin dicapai petani merupakan insentif yang didapat setelah melaksanakan inovasi tersebut. Insentif tersebut dapat berupa pendapatan yang semakin meningkat dari sebelumnya. Motivasi utama petani menerapkan inovasi benh jagung hibrida karena ingin meningkatkan pendapatannya melalui hasil yang melimpah dan mutu jagung yang dihasilkan baik. Selain karena pendapatan dan mutu yang baik, petani juga menerapkannya karena ingin menambah keterampilannya dalam menajalankan usahataninya. Usahatani jagung bukanlah pilihan usaha bagi petani, tetapi merupakan usaha yang memang harus dilakukan untuk memperoleh pendapatan dalam upaya memenuhi kebutuhan sehari-hari petani. oleh karenaya alasan menerapkan inovasi ini bukan karena untuk mengisi waktu luang.

Dari hasil uji Mann-Whitney diperoleh nilai probabiliti $(0,0740)$ lebih kecil dari alpha $10 \%$
$(0,1)$ maka tolak $\mathrm{H} 0$ artinya terdapat perbedaan yang signifikan antara tingkat motivasi petani early majority dan petani late majority dalam penerapan inovasi varietas jagung hibrida. Ratarata masing-masing skor motivasi petani early majority dan late majority secara berurutan adalah 18,675 dan 19.575. Perbandingan antara kedua katagori petani tersebut dapat dilihat pada Tabel 5. Tingkat motivasi late majority lebih tinggi dibandingkan dengan early majority.

Tabel 5. Hasil uji komparatif (Mann-Whitney) antara petani Early Majority dan Late Majority

\begin{tabular}{lcc}
\hline Kategori & N & Median \\
\hline Early majority & 40 & 18,00 \\
Late majority & 40 & 20,00 \\
\hline
\end{tabular}

Keterangan : taraf nyata $10 \%$

\section{Faktor-faktor yang Mempengaruhi Motivasi Petani}

Pada hasil analisis pengaruh regresi linier berganda padan masing-masing variabel indikator terhadap motivasi petani dalam menerapkan inovasi varietas jagung hibrida menunjukkan bahwa variabel pengalaman berusahatani jagung, jumlah tanggungan keluarga, sifat kosmopolit, ketersediaan modal, dan luas lahan garapan berkorelasi terhadap motivasi, sebaliknya variabel umur, pendidikan, ketersediaan sarana dan prasarana, dan intensitas 
penyuluh tidak berkorelasi terhadap motivasi petani dengan menggunakan taraf kepercayaan 90\%. Hasil analisis data mengenai pengaruh variabel indikator terhadap motivasi dapat dilihat pada Tabel 6 .

\section{Korelasi umur terhadap motivasi}

Para ahli banyak berpendapat bahwa semakin tua umur seseorang maka semakin berkurang motivasinya, sedangkan yang lebih muda cenderung lebih bersemangat untuk menerima informasiinformasi baru untuk diterapkan. Petani yang lebih muda cenderung miskin terhadap pengalaman dan keterampilan, namun lebih progresif terhadap inovasi baru. Kondisi inilah yang membentuk perilaku petani muda untuk lebih berani mengambil resiko (Soekartawi, 1988). Hal ini sejalan dengan Siagian (2004), yang mengatakan bahwa semakin tua umur seseorang makan tingkat kepuasannya cenderung semakin tinggi. Pada penelitian ini umur petani tidak berkorelasi terhadap motivasi petani dalam menerapkan inovasi varietas jagung hibrida. Hal ini dapat disebabkan karena rata-rata umur petani responden merupakan umur yang produktif, tidak ada perbedaan yang terlalu jauh antar petani. Rata-rata umur petani berada pada usia produktif yakni, early majority 49 tahun dan late majority 38 tahun. Kedua katagori petani yang berada pada usia produktif memiliki motivasi menjalankan usahatani jagungnya dengan menggunakan inovasi varietas jagung hibrida, untuk mendapatkan hasil yang lebih tinggibaik dariproduktivitas maupun pendapatannya.

Korelasi pendidikan terhadap motivasi Pendidikan pada penelitian ini adalah pendidikan formal yang diterima oleh petani. pada hasiluji korelasi pendidikan tidak berkorelasi terhadap motivasi petani. Hal ini menunjukkan bahwa pendidikan yang diterima oleh petani tidak menurunkan motivasi petani dalam penerapan inovasi varietas jagung hibrida. Sebesar 86 petani pendidikan petani masih tergolong rendah. Hal serupa juga terdapat pada penelitian yang dilakukan oleh Gafur (2009) yang tidak menemukan hubungan antara pendidikan dengan motivasi petani. Pendidikan secara formal tidak mendorong petani untuk menerapkan sebuah inovasi, namun hal tersebut dapat didukung melalui pendidikan nonformal seperti kegiatan penyuluhan sesuai dengan pengetahuan yang dibutuhkan petani. Meningkatnya pendidikan petani memungkinkan petani memilih bidang usaha lain atau inovasi yang lainnya sehingga dapat menyebabkan menurunnya motivasi petani dalam menerapkan inovasi varietas jagung hibrida. Petani yang masih memiliki keterbelakangan terhadap pendidikan diharapkan memiliki sikap lebih aktif, optimis, dan efektif yang akan membawa petani pada keadaan yang lebih produktif (Soetpomo, 1997).

\section{Korelasi pengalaman berusahatani jagung terhadap motivasi}

Pengalaman merupakan kepemilikan pengetahuan yang dialami seseorang dalam kurun

Tabel 6. Hasil analisis rank Spearman faktor-faktor yang berkorelasi dengan motivasi petani dalam penerapan inovasi varietas jagung hibrida

\begin{tabular}{lcc}
\hline \multicolumn{1}{c}{ Variabel Indikator } & Koefisien & P-value \\
\hline Umur & $-0,174$ & 0,177 \\
Pendidikan & 0,151 & 0,241 \\
Pengalaman berusahatani jagung & $-0,241$ & $0,060^{*}$ \\
Jumlah tanggungan keluarga & $-0,243$ & $0,057^{*}$ \\
Luas lahan garapan & 0,389 & $0,002^{*}$ \\
Sifat kosmopolit & 0,456 & $0,000^{*}$ \\
Ketersediaan sarana dan prasaran & $-0,003$ & 0,979 \\
Ketersediaan modal & $-0,263$ & $0,039^{*}$ \\
Intensitas penyuluh & 0,035 & 0,788 \\
\hline K
\end{tabular}

Keterangan : *berkorelasi jika nilai $\mathrm{p}<$ alpha $0,1(10 \%)$ 
waktu tertentu sebagai hasil belajar (Padmowihardjo, 1994). Pengalaman berusahatani jagung berkorelasi negatif terhadap motivasi petani dalam menerapakan inovasi varietas jagung hibrida, artinya meningkatnya pengalaman berusahatani jagung pada petani akan menurunkan motivasi petani untuk menerapkan inovasi. Hal ini dapat disebabkan adanya pengalaman dimasa lalu yang merugikan petani, sehingga petani tidak lagi menggunakan inovasi varietas jagung hibrida tersebut. Kerugian petani dalam melakukan usahatani jagung selama dua tahun terakhir banyak mengalami gagal panen akibat perubahan cuaca.

\section{Korelasi jumlah tanggungan keluarga terhadap motivasi}

Pada penelitian ini jumlah tanggungan keluarga memiliki korelasi bersifat negatif terhadap motivasi petani dalam menerapkan inovasi varietas jagung hibrida. Hal ini dapat disebabkan karena anggota keluarga dari petani responden sebagian besar memiliki tanggungan keluarga sebanyak 3-6 orang namun sebagian besar anggota keluarga tidak berperan aktif terhadap kegiatan usahatani. Jumlah anggota keluarga yang banyak namun pendapatn petani masih rendah akan berakibat pada rendahnya tingkat konsumsi. Kondisi ini dapat menyebabkan produktivitas petani dalam bekerja, kecerdasan, dan kemampuan berinvestasi akan menurun (Hernanto, 1993). Hal berbeda akan terjadi apabila besarnya jumlah anggota keluarga dapat menyumbangkan pengetahuan dan keterampilannya bagi kemajuan usahatani keluarga (Sabti, 1997). Jumlah keluarga yang semakin besar akan memotivasi petani untuk mencari penghasilan yang lebih banyak untuk memenuhi kebutuhan anggota keluarganya (Gohong, 1993). Korelasi luas lahan garapan terhadap motivasi Lahan merupakan lingkungan fisik yang terdiri atas iklim, relief, tanah, air, dan vegetasi serta benda yang ada di atasnya sepanjang ada pengaruhnya terhadap penggunaan lahan (Pujiharti, 2007).

Luas lahan garapan berkorelasi positif terhadap motivasi petani dalam menerapkan inovasi varietas jagung hibrida dengan koefisien bernilai positif, artinya setiap terjadi peningkatan pada luas lahan makan akan meningkatkan motivasi petani dalam menerapakan inovasi. Hal ini sejalan dengan Sinaga dan Kasryno (1980) yang mengatakan bahwa luas lahan garapan dapat mempengaruhi kecepatan petani dalam mengadopsi teknologi baru. Petani yang memiliki lahan luas cenderung akan gemar untuk mencoba inovasi, karena petani tidak takut terhadap resiko kegagalan dalam mencoba sebuah inovasi. Lahan yang luas memungkinkan petani untuk mencoba berbagai macam inovasi yang ada.

\section{Korelasi sifat kosmopolit terhadap motivasi}

Sifat kosmopolit berkorelasi positif terhadap motivasi petani dalam menerapkan inovasi varietas jagung hibrida, artinya semakin tinggi sifat kosmopolit petani akan meningkatkan motivasi petani untuk menerapkan inovasi. Sifat kosmopolit merupakan sifat individu yang cenderung menerima informasi mengenai sebuah inovasi. Petani yang memiliki sifat kosmopolit yang tinggi memiliki ciri-ciri, memiliki relasi yang banyak baik dengan sesama individu, kelmpok maupun kelembagaan, partisipasi sosial yang tinggi, serta aktif mencari informasi melalui berbagai media massa (Rogers, 1983). Hal tersebut dapat meningkatkan wawasan dan keterampilan petani dalam menjalankan usahataninya. Kondisi tersebut akan mendorong petani untuk tanggap terhadap peluang-peluang yang berpotensi menghasilkan pendapatan yang lebih tinggi (Wiriaatmadja, 1983).

\section{Korelasi ketersediaan sarana dan prasarana terhadap motivasi}

Ketersediaan sarana dan prasarana tidak berkorelasi terhadap motivasi petani dalam menerapakan inovasi varietas jagung hibrida. Hal ini dapat terjadi karena petani tidak mengalami kesulitan dalam memperoleh sarana produksi. Koefisien korelasi bersifat negatif yang artinya bahwa ketersediaan sarana dan prasarana tidak meningkatkan motivasi petani dalam penerapan inovasi varietas jagung hibrida. Input produksi yang dibutuhkan petani mudah didapatkan pada toko peralatan pertanian dan pedagang berjalan keliling desa, sehingga tidak mempengaruhi petani petani dalam menerapkan inovasi. 
Kondisi jalan pada wiliyah tersebut rata-rata tergolong baik karena jalannya beraspal sehingga tidak menyulitkan petani mengakses sarana produksi dan memasarkan hasil produksinya.

Rukka(2003)menyatakan bahwa sarana yang tersedia dalam jumlah, mutu, harga, dan waktu yang tepat akan sangat menunjang keberhasilan usahatani, serta adanya lembaga keuangan dapat memberikan pelayanan terhadap petani terkait dengan akses modal. Hal tersebut akan menimbulkan persepsi yang positif dari para petani sehingga mendorong mereka untuk melakukan usahataninya dengan baik.

\section{Korelasi ketersediaan modal terhadap motivasi}

Ketersediaan modal berkorelasi negatif terhadap motivasi petani dalam menerapkan inovasi varietas jagung hibrida. Hal ini disebabkan karena sebanyak $90 \%$ petani memiliki modal yang berasal dari pinjaman. Sebagian besar pinjaman tersebut berasal dari keluarga dan teman. Bunga pinjaman yang diterima petani cukup tinggi hingga $20 \%$. Selain itu biaya usahatani jagung hibrida lebih tinggi dibandingkan dengan non-hibrida. Hal ini dapat menyebabkan menurunnya motivasi petani untuk menerapkan inovasi varietas jagung hibrida karena beban yang ditrima oleh petani lebih berat.

Modal pada umumnya merupakan kekuatan yang sangat memnentukan kecepatan dalam menerapkan inovasi yang telah diberikan penyuluh kepada petani (Mardikanto, 1993). Namun berbeda halnya dengan petani responden, hal ini dapat terjadi karena akses modal yang dibutuhkan petani selalu tersedia walaupun modal yang dimiliki petani merupakan modal pinjaman baik melalui bank, keluarga atau teman dengan tingkat bunga yang berbeda-beda. Sebesar 90\% petani responden memiliki sumber modal melalui pinjaman. Jika petani mau menerapkan suatu inovasi, petani tidak menyerah pada kondisi tidak memiliki modal. Petani akan berusaha mendapatkan modal melalui pinjaman tersebut.

\section{Korelasi intensitas penyuluh terhadap motivasi}

Intensitaspenyuluh tidakberkorelasiterhadap motivasi petani dalam menerapkan inovasi varietas jagung hibrida dengan koefisien bernilai positif, artinya intensitas penyuluh tidak meningkatkan motivasi petani dalam menerapkan inovasi. Kinerja penyuluh yang baik akan mempengaruhi perilaku petani dengan meningkatkan kompetensi dan partisipasi petani (Bahua et al., 2010). Penyuluh dianggap berhasil apabila membawa perubahan terhadap petani pada aspek perilaku yang mengarah pada perbaikan taraf kehidupan (Mosher, 1987).

Kurangnya transparansi mengenai kegiatan penyuluhan juga menjadi masalah yang membuat petani tidak simpati terhadap penyuluh. Menurut kondisi lapang, terdapat penyuluh yang hanya memberikan segala informasi mengenai usahatani jagung melalui ketua kelompok tani saja. Penyuluh tidak berinteraksi langsung dengan seluruh petani yang ada, sehingga banyak petani yang tidak mengetahui siapa petugas penyuluh yang bertugas di daerahnya. Selain itu, dampak negatif lainnya adalah petani tidak mengetahui informasi-informasi penting mengenaiusahataninya.Petani cenderung melakukan usahataninya hanya berbekal dari pengalaman.

\section{Kesimpulan}

Kinerja petani hibrida dengan non hibrida memiliki perbedaan yang signifikan, dimana produktivitas dan pendapatan petani hibrida lebih tinggi dibandingkan dengan petani non hibrida. Harga yang berlaku pada kedua katagori petani tersebut tidak terdapat perbedaan, karena seluruh harga yang diberikan kepada petani ditentukan oleh pedagang pengumpul. Terdapat perbedaan antara tingkat motivasi petani early majority denganlate majority. Tingkat motivasi early majority lebih kecil dibandingkan dengan late majority. Faktor-faktor yang mempengaruhi motivasi adalah pengalaman berusahatani jagung, jumlah tanggungan keluarga, luas lahan garapan, sifat kosmopolit, dan ketersediaan modal. Sedangkan faktor-faktor yang tidak berpengaruh terhadap motivasi petani adalah umur, pendidikan, ketersediaan sarana dan prasarana, serta intensitas penyuluhan. 


\section{Daftar Pustaka}

Atkinson JW. 1964. An Introduction to Motivation. New York: The University Siries in Psychology, D. Van Nustrand Company, Inc.

[BPS] Badan Pusat Statistik 2013.Lombok Timur dalam Angka 2013. BPS Lombok Timur.

Bahua MI. 2010. Faktor-Faktor yang Mempengaruhi Kinerja Penyuluh Pertanian dan Dampaknya Pada Perilaku Petani Jagung di Provinsi Gorontalo. [Tesis]. Bogor (ID): Program Pascasarjana Institut Pertanian Bogor.

Exsact. Prospek dan Arah Pengembangan Agribisnis Jagung 1. [internet]. [diakses pada tanggal 13 Maret 2015].

Gafur. 2009. Motivasi Petani dalam Menerapkan Teknologi Produksi Kakao (Kasus Kecamatan Sirenja Kabupaten Donggala, Sulawesi Selatan. [Tesis]. Bogor (ID): Sekolah Pascasarjana Institut Pertanian Bogor.

Gohong. 1993. Tingkat Pendapatan dan Tingkat Kesejahteraan Petani serta Faktor-Faktor yang Mempengaruhinya pada Daerah Opsus Simpei Karuhei di Kabupaten Kapuas Provinsi Kalimantan Tengah. [Tesis]. Bogor (ID): Program Pascasarjana Institut Pertanian Bogor.

Gujarati. 2007. Dasar-Dasar Ekonometrika. Jilid 1. Jakarta (ID): Erlangga.

Handoko M. 1992. Motivasi Daya Penggerak Tingkah Laku. Yogyakarta (ID) : Kanisius.

Heady O.E dan J.H. Dillon. 1972. Agricultural Production. Iowa: Iowa State University Press.

Hernanto F. 1993. Ilmu Usahatani. Jakarta (ID): Swadaya.

Indraningsih KS. 2011. Pengaruh Penyuluhan Terhadap Keputusan Petani dalam Adopsi Inovasi Teknologi Usahatani Terpadu. Jurnal Agro Ekonomi 29.

Iskandar O. 2002. Etos Kerja, Motivasi, dan Sikap Inovatif Terhadap Produktivitas Petani. Makara, Sosial Humaniora 6.

Mardikanto T. 1993. Penyuluhan Pembangunan Pertanian. Surakarta (ID): Sebelas Maret University Press.

Mosher. 1987. Menggerakan dan Membangun
Pertanian. Jakarta : Yasaguna.

Padmowihardjo S. 1994. Metode Penyuluhan

Pertanian. Jakarta (ID): Universitas Terbuka.

Pujiharti S. 2007. Model Pengelolaan Lahan

Kring Berkelanjutan Pada Sistem Agribisnis

Tanaman Pangan. [Disertasi]. Bogor: Sekolah

Pascasarjana Institut Pertanian Bogor.

Pindyck RS, Rubinfeld DL. 2001. Microeconomics.

Edition Fifth. New York: Prentice Hall International, Inc.

Rogers EM. 1983. Diffusion of Innovations. Editions

Third. New York: The Free Press.

Rogers EM. 2003. Diffusion of Innovation. Edition

Fifth. New York. Free Press.

Rukka H. 2003. Motivasi Petani dalam Menerapkan

Ushatani Organik pada Padi Sawah (Kasus di

Desa Purwasari Kecamatan Dramaga Kabupaten

Bogor Provinsi Jawa Barat). [Tesis]. Bogor (ID):

Sekolah Pascasarjana Institut Pertanian Bogor.

Sabti A. 1997. Motivasi Petani dalam Pemanfaatan

Lahan Terbuka diantara Pohon Kelapa di

Kabupaten Aceh Timur. [Tesis]. Bogor (ID):

Program Pascasarjana, Institut Pertanian Bogor.

Setyobudi. Manajemen Agroekosistem (Manajemen

Tanaman). [Internet]. [diakses pada tanggal 6 Januari 2015].

Siagian SP. 2004. Manajemen Sumber Daya Manusia. Jakarta (ID): Bumi Aksara.

Soekartawi. 1988. Metodologi Penelitian Pertanian. Jakarta (ID): Rajawali Press.

Soekartawi. 1990. Teori Ekonomi Produksi, dengan pokok Bahasan Analisis Fungsi Cobb-Douglas. Jakarta: Rajawali Pers.

Soetpomo G. 1997. Kekalahan Manusia Petani. Yogayakarta (ID): Kanisius.

Suratiyah K. 2011. Ilmu Usahatani. Depok (ID): Penebar Swadaya.

Suriadi A. 2012. Model Pervarietasan Jagung Komposit Berpengairan Springkler Mendukung Kemandirian Petani di Lahan Kering Iklim Kering. Jurnal Balai Pengkajian Teknologi Pertanian 2.

Tajidan. 2014. Manajemen Rantai Pasok dan Integrasi Proses Bisnis Dalam Upaya Peningkatan Kesejahteraan Petani Jagung di Provinsi Nusa Tenggara Barat. [Disertasi]. Malang (ID): Program Pascasarjana Fakultas 
Jurnal Penyuluhan, Maret 2016 Vol. 12 No. 1

Pertanian Universitas Brawijaya.

Vizi. Karya Tulis Lahan Kering di NTB. [internet]. [diakses pada 28 februari 2015].

Vroom VH. 1964. Work and Motivation. New York: John Wiley and Son, Inc.

Wahjosumidjo. 1984. Kepemimpinan dan Motivasi. Jakarta (ID) : Ghalia Indonesia.

Winardi J. 2002. Motivasi dan Pemotivasian dalam Manajemen. Jakarta (ID) : PT. Raja Grafindo Persada. 